\title{
Pengaruh Inflasi, Kurs Dan Modal Kerja Terhadap Laba Perusahaan Perbankan
}

\author{
Silvia Meiliana dan Nuryasman M. N. \\ Fakultas Ekonomi dan Bisnis, Universitas Tarumanagara, Jakarta \\ Email: silviameiliana82@gmail.com; nuryasman@fe.untar.ac.id
}

\begin{abstract}
Abstrak: Penelitian ini bertujuan untuk menguji apakah (1) inflasi berpengaruh terhadap laba perbankan (2) kurs berpengaruh terhadap laba perbankan (3) modal kerja berpengaruh terhadap laba perbankan. Data diambil dengan metode purposive sampling, sehingga terkumpul 38 perusahaan perbankan. Teknik analisis data menggunakan teknik analisis regresi data panel. Data diolah dengan menggunakan Eviews 10.0. Hasil penelitian ini menunjukkan bahwa inflasi dan modal kerja mempunyai pengaruh positif terhadap laba. Sedangkan, kurs mempunyai pengaruh negatif terhadap laba.
\end{abstract}

Kata kunci : Inflasi, Kurs, Modal Kerja, Laba.

Abstract: The purpose of this research is to examine whether (1) inflation effect to banking profits (2) exchange rates effect to banking profits (3) working capital effects to banking profits. Data collection was done by purposive sampling method, so that 38 banking companies were collected. Data analysis techniques using panel data regression analysis techniques. Data is processed using Eviews 10.0. The results of this study indicate that inflation and working capital have a positive effect to profit. Meanwhile, the exchange rate has a negative effect to profit.

Keywords : Inflation, Exchange Rate, Working Capital, Profit.

\section{LATAR BELAKANG}

Perbankan memiliki peranan penting dalam kehidupan ekonomi di Indonesia yaitu sebagai penghimpun dana masyarakat untuk disalurkan kepada para pihak yang membutuhkan dana sesuai dengan Undang-Undang Republik Indonesia nomor 10 Tahun 1998, bank juga mempunyai peran yang penting dalam sistem perekonomian Indonesia yang semakin bertumbuh selaras dengan semakin bertumbuhnya juga kebutuhan masyarakat.

Dalam mengelola usahanya, sebuah bank juga harus menganalisis kinerja keuangannya, karena untuk mengetahui kondisi usaha saat ini dan sekaligus dapat memudahkan dalam menentukan kebijakan bisnis untuk masa yang akan datang. Dalam hal ini selain pihak manajemen yang memerlukan laporan keuangan sebagai evaluasi terhadap kinerja perusahaan selama periode tertentu, pihak investor juga sangat memerlukan laporan keuangan.

Laporan keuangan merupakan sarana utama untuk mengetahui kondisi perusahaan karena dalam laporan keuangan terdapat informasi-informasi keuangan yang dibutuhkan 
oleh para investor maupun pengguna laporan keuangan karena informasi yang terdapat dalam laporan keuangan dapat digunakan pihak yang berkepentingan atau pemakai laporan keuangan sebagai pertimbangan pengambilan keputusan ekonomi, namun terkadang perhatian pengguna laporan keuangan ataupun investor hanya terpusat pada informasi laba (Budiasih, 2009).

Bank Konvensional maupun Bank Syariah sendiri pada hakikatnya berorientasi pada laba (profit oriented), namun laba yang dimaksudkan adalah 2 hasil selisih antara pendapatan atas penanaman dana dan biaya - biaya yang dikeluarkan selama periode tertentu. Sehingga dari segala sumber dana akan dialokasikan untuk memperoleh pendapatan dan tingginya pendapatan merupakan tanda kinerja yang baik pada bank tersebut.

Laba dapat dipengaruhi oleh faktor internal dan eksternal. Karenanya Perbankan harus mampu membangun citra perbankan yang baik agar dapat menarik investor untuk berinventasi dan juga nasabah untuk dapat menyimpan uang mereka. Maka perbankan harus dapat mengatasi faktor eksternal seperti inflasi yang melanda perekonomian Indonesia dan juga kurs yang berubah-ubah setiap harinya. Selain faktor-faktor eksternal yang mempengaruhi Laba faktor internal juga turut serta memberikan pengaruh terhadap fluktuasi Laba perusahaan perbankan. Faktor internal yang mempengaruhi yaitu Modal Kerja. Oleh karenanya Penelitian yang peneliti lakukan untuk mengukur laba bank menggunakan 3 variabel yaitu Infllasi, Kurs dan Modal Kerja

Menurut penelitian Setiawan \& Hanryono (2016) menunjukkan bahwa inflasi tidak berpengaruh terhadap laba. Penelitian Allaily Mar'atus Solikhah (2015) menunjukkan bahwa nilai tukar mempunyai hubungan signifikan terhadap laba dan inflasi berpengaruh negative terhadap laba. Menurut Naily Hida (2018) menunjukkan bahwa modal kerja tidak berpengaruh signifikan terhadap laba.

\section{KAJIAN TEORI}

Menurut Kopong dan Nurzanah (2016) signal theory menunjukan adanya asimetri informasi anatar manajemen perusahaan dengan pihak yang memerlukan informasi. Oleh sebab itu manager perlu menyediakan informasi kepada para pihak yang mempunyai kepentingan dengan membuat laporan keuangan yang di publikasikan. Manajer memberikan informasi melalui laporan keuangan jika mereka menerapkan kebijakan akuntansi konservatisme dimana mereka mampu menghasilkan laba yang lebih tinggi dan berkualitas, konsep ini mencegah perusahaan melakukan tindakan membesar besarkan laba dengan pengguna menyajikan laba dan aktiva yang tidak overstate.

Teori sinyal menunjukan tentang bagaimana seharusnya perusahaan memberikan sinyal kepada pembaca laporan keuangan berupa infomasi mengenai apa yang dilakukan manajemen untuk merealisasikan keinginan pemiliknya.

Fahmi (2011:2) menyatakan: "laporan keuangan merupakan suatu informasi yang menggambarkan kondisi keuangan suatu perusahaan, dan lebih jauh informasi tersebut dapat dijadikan sebagai gambaran kinerja keuangan perusahaan tersebut. Dengan kata lain laporan keuangan merupakan suatu informasi yang menggambarkan kondisi keuangan suatu perusahaan dan informasi tersebut dapat dijadikan sebagai gambaran kinerja keuangan dari perusahaan tersebut." 
Basel II bertujuan untuk meningkatkan keamanan dan kesehatan sistem keuangan, dengan fokus dalam perhitungan modal berbasis risiko, supervisory review process dan market discipline (Budisantoso \& Nuritomo., 2014:9). Secara umum kerangka Basel II terdiri dari 3 pilar yaitu : minimum capital requirements, supervisory review process, market discipline.

Berikut kerangka pemikiran dalam penelitian ini :

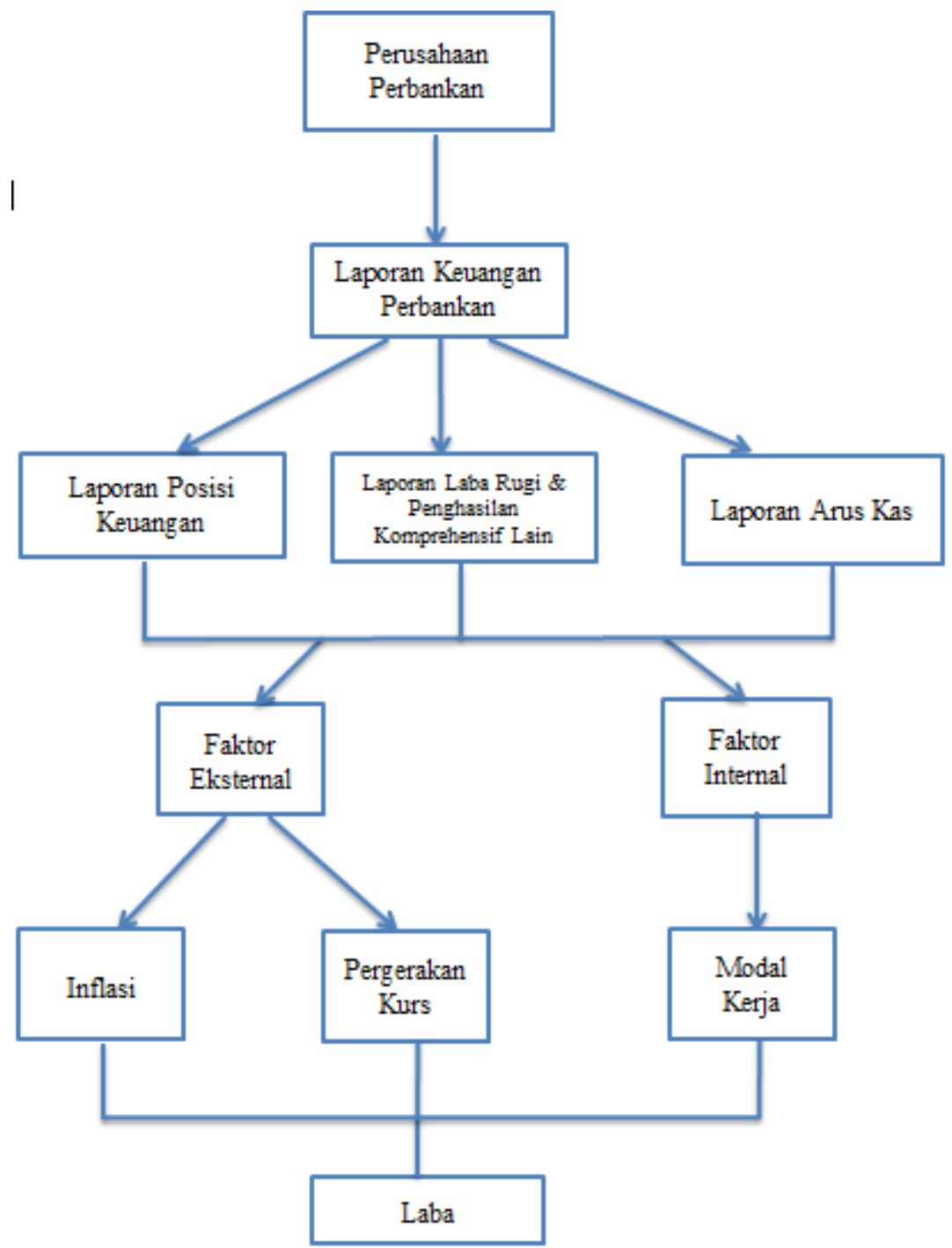

Gambar 1. Kerangka pemikiran

Inflasi merupakan salah satu faktor eksternal yang dapat mempengaruhi kinerja perbankan. Inflasi adalah suatu keadaan di bidang ekonomi yang sedang diterpa oleh suatu kenaikan di tingkat harga yang paling tinggi serta tidak bisa untuk dicegah atau pun dikendalikan kembali. Perbankan harus mengatasi inflasi yang melanda perekonomian Indonesia. Agar dapat menarik investor untuk berinventasi dan juga nasabah untuk dapat menyimpan uang mereka. Karena dengan adanya inflasi dapat memberikan keuntungan 
untuk bank sebab masyarakat lebih memilih untuk menyimpan uang mereka daripada untuk berbelanja barang. Hal tersebut membuat inflasi sangat berpengaruh terhadap laba perbankan.

Untuk menilai kinerja bank salah satu factor eskternal yang penting adalah kurs. Menurut (Nazir 1988:38)Kurs merupakan harga satu satuan mata uang asing dalam uang dalam negeri. Dengan kata lain kurs adalah harga suatu mata uang jika ditukarkan dengan mata uang lainnya. Menurut FASB (Financial Accounting Standard Board) nilai tukar adalah rasio antara satu unit mata uang dengan jumlah mata uang lainnya yang dapat ditukarkan pada suatu waktu tertentu. Kurs atau nilai tukar merupakan sebuah perjanjian yang dikenal sebagai nilai tukar mata uang terhadap pembayaran saat kini atau di kemudian hari, antara dua mata uang masing-masing negara atau wilayah. Nilai tukar yang sering digunakan secara internasional adalah nilai tukar rupiah terhadap dollar. Karena dollar adalah mata uang yang relatif stabil dalam perekonomian. Dalam kegiatan transaksi, nilai tukar akan mata uang asing menjadi perhatian bank karena hal tersebut sangat mempengaruhi tingkat profitabilitas bank. Dengan terjadinya fluktuasiakan nilai tukar mata uang asing, bank dapat memperoleh pendapatan berupa fee dan selisih kurs sehingga dapat meningkatkan laba.

Selain factor eksternal, factor internal juga harus di perhatikan untuk mengetahui kinerja perbankan. Factor internal yang ada salah satunya Modal kerja. Modal Kerja adalah modal yang seharusnya tetap ada dalam perusahaan sehingga operasional perusahaan menjadi lebih lancar serta tujuan akhir perusahaan untuk menghasilkan laba akan tercapai. Modal kerja merupakan modal yang diperlukan untuk membiayai seluruh kegiatan supaya usaha berjalan sesuai dengan rencana yang dibuat. Modal kerja adalah uang tunai dan aktiva yang mudah diuangkan untuk mendanai kegiatan operasional perusahaan seharihari. Modal kerja Jumingan (2006) adalah jumlah aktiva lancar pada neraca perusahaan. Konsep modal kerja bersih yaitu pengurangan antara aktiva lancar atau aset saat ini dengan pasiva lancar/hutang lancar. Sehingga diketahui bahwa terdapat modal kerja bersih dan modal kerja kotor.

Modal kerja merupakan nilai yang dipakai dalam pengukuran atau penilaian tingkat efektifitas modal kerja pada suatu periode tertentu. Nilai tersebut dapat dihitung melalui Aktiva Lancar dikurangi degan Hutang Lancar. Sehingga Modal Kerja dapat sangat mempengaruhi ataupun tidak mempengaruhi Laba pada perusahaan perbankan.

Dari pembahasan diatas, maka terbentuklah kerangka pemikiran hipotesis seperti yang digambarkan pada gambar 1. laba merupakan salah satu faktor yang mempengaruhi keuangan suatu perusahaan, sehingga pentingnya tata kelola perusahaan maupun pengelolaan keuangan yang baik dan benar. Oleh sebab itu dapat dirumuskan hipotesis sebagai berikut :

H1 : Pengaruh Inflasi, Kurs dan Modal Kerja secara bersama-sama merupakan penentu yang signifikan terhadap laba. .

H2 : Pengaruh Inflasi, merupakan penentu yang signifikan terhadap laba.

H3 : Pengaruh Kurs, merupakan penentu yang signifikan terhadap laba.

H4 : Pengaruh Modal Kerja, merupakan penentu yang signifikan terhadap laba. 


\section{METODOLOGI}

Metode pengambilan sampel yang dilakukan didalam penelitian ini adalah metode sensus. Metode ini adalah cara pengumpulan data dimana seluruh elemen populasi diselidiki satu persatu. Oleh sebab itu, data yang terkumpul dalam penelitian ini adalah 38 perusahaan perbankan. Dalam penelitian ini menggunakan desain penelitian kausal komparatif. Penelitian ini menggunakan metode kuantitatif, dimana dalam metode ini lebih menekankan penghitungan, pengukuran seperti menggunakan simbol angka. Sumber data ini yang dipakai dalam penelitian ini adalah data sekunder, dikarenakan sumber data yang diperoleh peneliti dari pihak yang terpercaya.

Operasionalisasi variabel yang dilakukan pada variabel dependen dalam penelitian ini adalah menggunakan Laba. Maka rumus dari Laba adalah sebagai berikut :

$$
\text { Laba }=\frac{\text { Laba Bersih Tahun berjalan }- \text { laba bersih tahun sebelumnya }}{\text { laba bersih tahun sebelumnya }}
$$

Sedangkan variabel independen dalam penelitian ini berkaitan dengan tata kelola perusahaan yaitu Inflasi Menurut M. Natsir (2014:266) dirumuskan sebagai berikut:

$$
\begin{aligned}
& \text { Inflasi }= \\
& \frac{I H K_{t}-I H K_{t-1}}{I H K_{t-1}} \times 100 \%
\end{aligned}
$$

Selain itu, Kurs di ukur dengan cara Moving Average Menghitung jumlah rata-rata valuta asing pada rentang waktu tertentu.

Kurs=Tingkat Kursper tahun

Modal Kerja dapat diukur dengan cara aktiva lancar pada laporan keuangan dikurangi dengan hutang lancar yang ada pada laporan keuangan. Berikut adalah perhitungannya:

Modal Kerja $=$ Aktiva Lancar - Hutang Lancar

Dalam penelitian ini teknik pengolahan data yang digunakan adalah Statistik Deskriptif, Analisis Data Panel, Analisis Regresi Linear Berganda, Uji F (bersama-sama), Uji T (Parsial), Uji asumsi klasik, Koefisien Determinasi dengan menggunakan aplikasi Eviews.

\section{HASIL DAN PEMBAHASAN}

\section{Hasil Analisis Data}

\section{Statistik Deskriptif}

Pada gambaran deskriptif, akan dilakukan pengolahan data untuk mengetahui mean, maximum, minimum, dan standard deviation dari variabel dependen yaitu laba dan variabel independen yaitu inflasi, kurs dan modal kerja. Berikut ini adalah tabel ringkasan gambaran deskriptif: 
Tabel 1. Gambaran deskriptif

\begin{tabular}{|c|c|c|c|c|}
\hline & IF & K & L & MK \\
\hline MEAN & 124.2558 & 13308.00 & 2566712 & 13076502 \\
\hline MEDIAN & 124.6680 & 13451.00 & 172917.5 & 2332766 \\
\hline MAXIMUM & 133.5550 & 14318.00 & 29044334 & $2.67 \mathrm{E}+08$ \\
\hline MINIMUM & 113.2180 & 11938.00 & -6483084. & 13217.00 \\
\hline STD. DEV. & 7.086966 & 769.4395 & 6074745. & 36920493 \\
\hline OBSERVATION & 190 & 190 & 190 & 190 \\
\hline
\end{tabular}

Sumber : diolah penulis

Statistik deskriptif Inflasi memiliki nilai minimum dan maksimum berturutturut adalah sebesar 113.2180 dan 133.5550. Tahun yang memiliki tingkat Inflasi terendah adalah pada tahun 2014, sedangkan tahun yang memiliki tingkat Inflasi tertinggi adalah Tahun 2018. Nilai rata-rata variabel Inflasi adalah 124.2558 dan standar deviasi sebesar 7.086966.

Statistik deskriptif Kurs memiliki nilai minimum dan maksimum berturut-turut adalah sebesar 11938.00 dan 14318.00. Tahun yang memiliki tingkat Pergerakan Kurs terendah adalah Tahun 2014, sedangkan tahun yang memiliki tingkat Pergerakan Kurs tertinggi adalah tahun 2018. Nilai rata-rata variabel Pergerakan Kurs adalah 13308.00 dan standar deviasi sebesar 769.4395.

Statistik deskriptif Laba memiliki nilai minimum dan maksimum berturut-turut adalah sebesar -6483084 dan 29044334. Bank yang memiliki tingkat Laba terendah adalah Bank Permata pada tahun 2016, sedangkan bank yang memiliki tingkat Laba tertinggi adalah Bank Rakyat Indonesia tahun 2017. Nilai rata-rata variabel Laba adalah 2566712 dan standar deviasi sebesar 6074745.

Statistik deskriptif Modal Kerja memiliki nilai minimum dan maksimum berturut-turut adalah sebesar 13217.00 dan 2.67E+08 / 266907155 Bank yang memiliki tingkat Modal Kerja terendah adalah Bank Pembangunan Daerah Banten pada tahun 2018, sedangkan bank yang memiliki tingkat Modal Kerja tertinggi adalah Bank Mandiri pada tahun 2018. Nilai rata-rata variabel Modal Kerja adalah 13076502 dan standar deviasi sebesar 36920493.

\section{Analisis Data Panel}

Menurut Widarjono (2013: 355), model regresi data panel merupakan model yang menunjukkan hubungan variabel bebas terhadap variabel dalam cross section dan time series.

Uji Chow. Untuk menentukan pendekatan yang tepat terhadap regresi data panel, maka diperlukan uji Chow. Uji Chow menentukan apakah regresi data panel menggunakan model common effect atau fixed effect. Jika probabilitas $>0.05$, maka H0 diterima, sehingga model yang tepat adalah common effect. Jika probabilitas $<0.05$, maka $\mathrm{H} 0$ ditolak, sehingga model yang tepat adalah fixed effect. 
Hasil Uji Chow menunjukkan Probabilitas cross-section Chi-square menunjukan angka sebesar 0.0000 dengan nilai $\alpha=0.05$. Artinya $\mathrm{H}_{0}$ tidak diterima oleh karena itu model fixed effect dipakai sebagai regresi data panel.

Jika hasil uji Chow menghasilkan model fixed effect, maka tahap selanjutnya adalah menggunakan uji Haussman.

Uji Hausman. Setelah uji Chow menunjukan model fixed effect pada data panel, maka selanjutnya digunakan uji Hausman. Uji Haussman diperlukan untuk mementukan estimasi pendekatan mana yang paling tepat antara fixed effect model maupun random effect model. Jika probabilitas $>0.05$, maka $\mathrm{HO}$ diterima, sehingga modelyang digunakan adalah random effect. Jika probabilitas $<0.05$, maka $\mathrm{HO}$ ditolak, sehingga model yang tepat adalah fixed effect.

Hasil Uji Hausman menunjukkan Probabilitas cross section random menunjukan angka sebesar 1.0000 dengan nilai $\alpha=0.05$. Artinya $\mathrm{H}_{0}$ tidak ditolak, sehingga model yang digunakan random effect. Dari kesimpulan di atas, berikut ini adalah data tabel analisis regresi model random effect.

Persamaan regresi dari model random effect dari keseluruhan perusahaan sektor perbankan yang telah go-public dan terdaftar di Bursa Efek Indonesia selama periode 2014-2018, yaitu:

\begin{tabular}{|c|c|c|c|}
\hline$L_{i t}=51$ & +61642 & +-465.2 & $t+1$ \\
\hline Std.error 2086025 & 37082.41 & 340.3046 & 0.010847 \\
\hline -stat & {$[1.662320]$} & {$[-1.367048]$} & {$[4.107614]$} \\
\hline
\end{tabular}

Persamaan regresi di atas menunjukan bahwa Inflasi memiliki pengaruh positif dan tidak signifikan terhadap Laba dimana setiap kenaikan $1 \%$ terhadap Inflasi, maka Laba akan mengalami kenaikan sebesar 515659.5 apabila Kurs dan Modal Kerja bersifat konstan. Kurs memiliki pengaruh negatif dan tidak signifikan terhadap Laba dimana setiap kenaikan 1\% terhadap Kurs, maka Laba akan mengalami penurunan sebesar 465.2129 apabila Inflasi dan Modal Kerja bersifat konstan. Dan Modal Kerja memiliki pengaruh positif dan signifikan terhadap Laba. Apabila Modal Kerja mengalami kenaikan sebesar $1 \%$, maka Laba akan mengalami kenaikkan sebesar $0.044555 \%$ apabila Inflasi dan Kurs bersifat konstan.

Kesalahan baku (standard error) dari intersep sebesar 2086025, Inflasi sebesar 37082.41, Kurs sebesar 340.3046, dan Laba sebesar 0.010847.

\section{Uji F (bersama-sama)}

Hipotesis pertama dilakukan dengan uji-F yaitu menguji koefisien regresi secara bersama-sama apakah semua variable bebas jika bersama-sama dapat mempunyai pengaruh untuk variable dependen. Dalam uji ini Arieffianto (2012: 21) menjelaskan paling sedikit terdapat satu variable independen yang merupakan prediktor signifikan terhadap variable independen dalam penelitian ini digunakan alpha sebesar 0.05 (5\%) jika tingkat probabilitas lebih kecil dari alpha maka $\mathrm{H} 0$ ditolak dan $\mathrm{H} 1$ tidak ditolak.

Berdasarkan hasil uji F Tingkat probabilitas nya sebesar 0.000171 lebih kecil dari 0.05 maka kesimpulannya Ho tidak diterima berarti inflasi, kurs, dan modal kerja secara bersama-sama mempunyai pegaruh yang signifikan terhadap laba. 


\section{Uji T (parsial)}

Hipotesis ini menggunakan Uji-t yang menguji koefisien regresi secara parsial, daji menguji secara satu per satu variable bebas terhadap variable dependen. Jika probabilitas kurang dari 0.05 (alpha) maka Ho ditolak dan sebaliknya.

Tabel 2. Hasil Uji T

\begin{tabular}{|c|c|c|}
\hline Variable & Coefficient & Prob. \\
\hline C & 515659.5 & 0.8050 \\
\hline IF & 61642.81 & 0.0981 \\
\hline K & -465.2129 & 0.1733 \\
\hline MK & 0.044555 & 0.0001 \\
\hline
\end{tabular}

Sumber: diolah penulis

Berdasarkan dari tabel 5, hasil uji T menunjukkan bahwa hasil tingkat probabilitas sebesar $0.0981>0.05$ maka bisa ditarik kesimpulan inflasi tidak mempunyai pengaruh yang signifikan terhadap laba. Tingkat probabilitas dalam tabel 5 sebesar $0.1733>0.05$ maka bisa ditarik kesimpulan bahwa kurs tidak mempunyai pengaruh yang signifikan terhadap laba. Tingkat probabilitas dalam tabel 5 sebesar $0.0001<0.05$ maka bisa ditarik kesimpulan modal kerja mempunyai pengaruh yang signifikan terhadap laba.

\section{Uji Asumsi Klasik}

1) Uji Multikolerianitas

Uji ini digunakan untuk melihat keterikatan antar variable bebas yang digunakan dalam penelitian. Jika terjadi multikolerianitas maka variable tersebut dapat berubah nilainya karena variable lain sehingga independensinya kurang.

Menurut Ajija dkk (2011:35) ada atau tidaknya multikolerianitas dapat diketahui dengan melihat kolerasi tiap variable, jika kolerasinya melebihi 0.8 maka terjadi multikolerianitas.

Tabel 3. Hasil Uji Multikolerianitas

\begin{tabular}{||cccc|}
\hline & IF & K & MK \\
\hline \hline IF & 1.000000 & 0.910725 & 0.044797 \\
K & 0.910725 & 1.000000 & 0.038370 \\
MK & 0.044797 & 0.038370 & 1.000000 \\
\hline
\end{tabular}

Sumber: diolah penulis 
Dari table ditemukan adanya kolerasi antar inflasi dan kurs karena mempunyai nilai di atas 0.8 selain dengan variable itu sendiri maka terdapat masalah multikolerianitas di variable independen regresi ini.

Yang memang akan terjadi multikolerianitas karena jika inflasi meningkat akan secara otomatis menaikkan kurs yang berlaku pada saat kenaikan inflasi tersebut terjadi.

\section{Koefisien Determinasi}

Berdasarkan hasil Uji Koefisien Determinasi nilai $\mathrm{R}^{2}$ sebesar 0,101609 (10,16\%). Hasil pengujian ini menunjukkan bahwa sebesar $10,16 \%$ variabel dependen laba (dapat dijelaskan oleh variabel-variabel independen, antara lain inflasi, kurs dan modal kerja. Sedangkan sisanya sebesar $89,84 \%$ dapat dijelaskan oleh variabel-variabel lain di luar penelitian ini.

\section{DISKUSI}

Berdasarkan hasil pengujian yang dilakukan dalam penelitian ini inflasi mempunyai pengaruh positif dan tidak signifikan terhadap laba. Hal ini disebabkan adanya kenaikan harga secara terus menerus, yang menyebabkan bertambahnya kebutuhan dana masyarakat (berkurangnya menabung) dan kredit yang diberikan bank bertambah. Kurs mempunyai pengaruh negatif dan tidak signifikan terhadap laba. Artinya dengan meningkatnya kurs dapat menyebabkan investasi menurun. Karena mayoritas tabungan dan kredit yang disalurkan bank dalam bentuk mata uang rupiah. Sedangkan modal kerja mempunyai pengaruh yang positif dan signifikan terhadap laba. Artinya semakin tinggi modal kerja yang dimiliki perusahaan maka laba yang dihasilkan akan meningkat. Karena kinerja perusahaan dalam menghimpun dana dan menyalurkannya dalam bentuk kredit tercermin dari modal kerja.

Berdasarkan hasil dari hasil uji statistik t, menunjukkan nilai probabilitas dari Inflasi terhadap Laba sebesar 0,0981 > $\alpha$ sehingga, yang berarti Inflasi tidak memiliki pengaruh signifikan terhadap Laba. Hasil dari penelitian ini sejalan dengan penelitian yang dilakukan Daniel Imanuel Setiawan \& Hanryono (2016) yang menyatakan Variabel inflasi secara parsial tidak berpengaruh terhadap pertumbuhan laba bank swasta devisa yang terdaftar di BEI pada periode 2009-2013. Penelitian tersebut juga didukung dengan penelitian yang dilakukan oleh Allaily Mar'atus Solikhah (2015) yang menyatakan bahwa tingkat inflasi berpengaruh negative terhadap pertumbuhan laba/ laba serta dari penelitian Nuryasman \& Yessica (2017) Inflasi secara parsial tidak signifikan terhadap harga saham perusahaan pada sektor real estate dan properti di Bursa Efek Indonesia. Sedangkan penelitian yang dilakukan oleh Dwijayanthy dan Naomi (2009) tidak sejalan dengan penelitian sebelumnya, hasil penelitiannya menyatakan bahwa inflasi berpengaruh signifikan pada profitabilitas. Sama dengan penelitian yang dilakukan oleh Sahara (2013) yang menyatakan bahwa tingkat inflasi mempunyai pengaruh yang signifikan terhadap pertumbuhan laba.

Hubungan antara Kurs dengan Laba adalah negative dengan koefisien regresi sebesar - 465,2129 yang menunjukkan bahwa, jika Kurs naik satu satuan dan variabel independen yang lain dianggap tetap maka Laba akan turun sebesar 465,2129 satuan. Hubungan 
negatif ini adalah Bila nilai tukar rupiah terus mengalami pelemahan, maka akan memicu inflasi. Dengan meningkatnya inflasi dapat mengurangi laba pada perbankan.

Dari hasil uji statistik t, menunjukkan bahwa Modal Kerja terhadap Laba sebesar $0,0001<\alpha$ yang berarti Modal Kerja memiliki pengaruh signifikan terhadap Laba. Hasil penelitian ini sejalan dengan penelitian yang dilakukan oleh Tengku Putri Lindung (2015) yang menemukan bahwa Modal Kerja secara statistik memiliki pengaruh yang signifikan terhadap Laba. Namun hasil ini tidak sejalan dengan penelitian yang dilakukan oleh Naily Hida (2018) yang menunjukkan bahwa Modal Kerja tidak berpengaruh terhadap Profitabilitas perbankan.

\section{KESIMPULAN}

Berdasarkan penelitian ini, masih banyak kekurangan sehingga ada beberapa saran yang di berikan sebagai berikut :

1. Bagi peneliti berukutnya, disarankan untuk meneliti variabel-variabel lain yang belum digunakan pada peneltian ini sehingga hasil yang didapatkan dapat lebh luas. Penelitan ini hanya menggunakan sektor perbankan, diharapkan ada penelitian lainnya dengan variabel yang sama untuk meneliti sektor lainnya dengan variabel yang sama sehingga dapat diketahui variabel yang mana yang paling dominan di setiap sektor yang berbeda.

2. Diharapkan manajemen perusahaan khususnya pada perusahaan sektor perbankan yang terdaftar di Bursa Efek Indonesia dalam periode 2014-2018 untuk memperhatikan Inflasi, Kurs dan Modal Kerjua sehingga dapat meningkatkan kinerja keuangan perusahaan secara signifikan. Untuk meningkatkan Laba secara signifikan, disarankan manajemen perusahaan lebih memperhatikan modal kerja karena dalam modal kerja memiliki pengaruh yang signifikan terhadap financial distress.

\section{DAFTAR PUSTAKA}

Agustina, Rice (2016), Analisa Faktor-faktor yang Mempengaruhi Pertumbuhan laba dengan ukuran Perusahaan sebagai Variable Moderating pada perusahaan manufaktur yang Terdaftar di Bursa Efek Indonesia, Jurnal Wira Ekonomi Mikroskil Volume 6 No.1.

Amalia, Nuril Hidayati (2014), Pengaruh Inflasi, BI Rate dan Kurs Terhadap Profitabilitas Bank Syariah di Indonesia, AN-NISBAH, Vol. 01, No. 01, Oktober 2014

Anggraeni, Fitria. (2015). Pengaruh CAR, NIM, KAP, LDR, dan Inflasi terhadap Pertumbuhan Laba Periode 2008-2013 Skripsi.FE. Semarang: Universitas Pandanaran.

Allaily Mar'atus Solikhah (2015) Analisis Dampak Kondisi Ekonomi Terhadap Pertumbuhan Laba Bank Syariah Indonesia Periode Q1 2007- Q4 2014 skripsi Fakultas Ekonomi dan Bisnis. Surabaya: Universitas Airlangga

Badan Pusat Statistik. Indeks Harga Konsumen dan Inflasi Bulanan Indonesia, (20142018)

http://www.bps.go.id

Bank Indonesia, Laporan Moneter-Informasi Kurs, di akses tanggal 25 Mei 2019 
Daniel, Imanuel Setiawan, \& Hanryono (2016). Analisis Pengaruh Kinerja Keuangan Bank, Tingkat Inflasi, dan BI Rate Terhadap Pertumbuhan Laba (Studi pada Bank Swasta Devisa yang Terdaftar pad Bursa Efek Indonesia Periode 2009-2013), Journal of Accounting and Business Studies, Vol 1, No. 1, \#ISSN2540-8275.

Darmawi, Herman. 2011. Manajemen Perbankan. Jakarta : PT Bumi Aksara.

Diana Chylvia Oroh , David P. Saerang, Winston Pontoh (2016), Pengaruh Nilai Tukar Rupiah, Inflasi dan Suku Bunga Terhadap Net Profit Margin pada Industri Barang Konsumsi yang Go Public di Bursa Efek Indonesia Periode 2010-2014, Jurnal Berkala Ilmiah Efisiensi, Volume 16 No. 03 Tahun 2016

Fauziah, Ravika. (2013). Analisis Pengaruh Inflasi Terhadap Tingkat Profitabilitas Bank Muamalat Indonesia Dan Bank Central Asia (BCA) Tahun 2007-2011. Surabaya: Universitas Negri Surabaya.

Fitri Zulifiah \& Joni Susilowibowo (2014), Pengaruh Inflasi, BI Rate, Capital Adequacy Ratio (CAR), Non Performing Finance (NPF), Biaya Operasional Dan Pendapatan Operasional (BOPO) Terhadap Profitabilitas Bank Umum Syariah Periode 20082012, Jurnal Ilmu Manajemen, Volume 2 Nomor 3 Juli 2014

Frank J. Fabozzi dan Franco Modigliani, Capital Markets (Prentice Hall, New Jersey: 1992) dalam The Fei Ming, Day Trading Valuta Asing (Gramedia, Jakarta: 2002)

Gunawan, A., \& Wahyuni, S. F. (2013). Pengaruh Rasio Keuangan terhadap Pertumbuhan Laba pada Perusahaan Perdagangan di Indonesia. Jurnal Manajemen \& Bisnis. Volume n13. Nomor1, 63-84.

Karim Pakravan. Bank capital: the case against Basel, Journal of Financial Regulation and Compliance Vol.22No.3,2014

Mankiw, N.Gregory. 2007. Makroekonomi, Edisi Keenam. Jakarta : Erlangga

Nuryasman dan Yessica (2017). Determinan Harga Saham Sektpr Properti dan Real Estate di Bursa Efek Indonesia. Jurnal Manajemen/Volume XXI, No. 02, Juni 2017: 270281Nomor1, 63-84.

Sahara, A. Y. (2013). Analisis Pengaruh Inflasi, Suku Bunga BI, dan Produk Domestik Bruto terhadap Return On Asset Bank Syariah di Indonesia. Jurnal Ilmu Manajemen. Volume 1. Nomor 1, 149-157.

Tengku Putri Lindung Bulan (2015), JURNAL MANAJEMEN DAN KEUANGAN, VOL.4, NO.1, MEI 2015

Wibowo, E. S., \& Syaichu, M. (2013). Analisis Pengaruh Suku Bunga, Inflasi, CAR, BOPO, dan NPF terhadap Profitabilitas Bank Syariah. Journal of Management. Universitas Dipornegoro. Volume 2. No.2.

Zulfiah, Fitri \& Joni Susilo Wibowo. 2014. Pengaruh Inflasi, Bi Rate, Capital Adequacy Ratio (CAR), Non Performing Finance (NPF), Biaya Operasional Dan Pendapatan Operasional (BOPO) Terhadap Profitabilitas Bank Umum Syariah Periode 20082012. Jurnal Ilmu Manajemen: Volume 2, Nomor 3, Juli 2014 